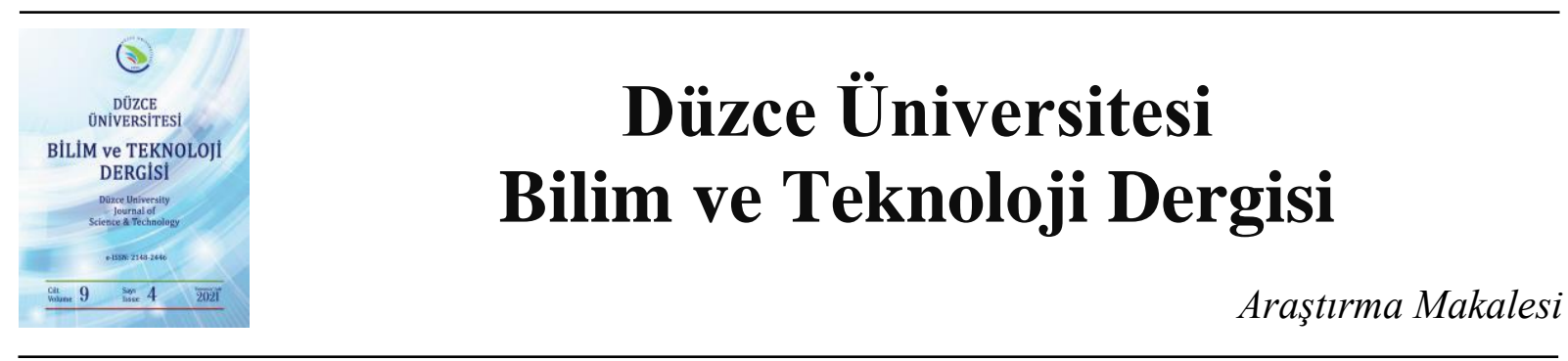

\title{
Yat Limanlarındaki Güneş Enerji Santralleri Panel Eğim Açısı Değişiminin Elektrik Üretimi Açısından İncelenmesi
}

\author{
iD Ali Riza DAL ${ }^{*}$ \\ Ulaştırma ve Altyapı Bakanlı̆̆l, Ankara, TÜRKIYYE \\ * Sorumlu yazarın e-posta adresi: ardal1969@gmail.com \\ DOI: $\quad$ 10.29130/dubited.869639
}

\section{ÖZET}

Dünya nüfusundaki artış, sanayideki büyüme ve gelişen teknoloji enerji tüketim talebini artırmaktadır. Enerji tüketimindeki bu artış iklim değişikliğine sebep olmaktadır. Güneş Enerjisi Santrallerinin (GES) hem iklim değişikliğini hem de ülkemizin enerjide dışa bağımlılığını azaltıcı bir etkisi vardır. GES'de elektrik üretimi için güneş panelleri kullanılmaktadır. GES'de güneşten en üst seviyede yararlanmak amaçlanmaktadır. Literatürde; yıllık ve mevsimsel olarak panel eğim açılarının değişim ile ilgili çalışmalar da mevcuttur. GES konut ve endüstrinin birçok alanında kullanılmasına rağmen yat limanlarında kullanılmamaktadır. Bu çalışmanın amacı bir yat limanı elektrik ihtiyacı için GES'den maksimum seviyede faydalanmaktır. Bu amaç kapsamında GES'de güneş panellerinin aylık optimum eğim açısının değiştirilmesi ile GES’in üretim veriminin artırılması analiz edilmiştir.

Analiz için Fethiye İlçesindeki bir yat limanının elektrik ihtiyacının $1500 \mathrm{~kW}$ gücünde olan GES ile tedarik edilebileceği tespit edilmiştir. Bu çalışmada Fotovoltaik Coğrafi Bilgi Sistemi (PVGIS) simülasyon programı kullanılmıştır. Aynı şekilde GES panellerinin elektrik üretimi optimum eğim açılarında $\left(0^{\circ}, 8^{\circ}, 13^{\circ}, 19^{\circ}, 24^{\circ}\right.$, $31,7^{\circ}, 35^{\circ}, 40^{\circ}, 49^{\circ}, 50^{\circ}, 59^{\circ}$ ) aylık bazda ayrı ayrı bulunmuştur. GES'de kullanılan panellerde aylık optimum eğim açılarının yılda 2, 3, 4, 5, 6, 7 ve 8 defa değiştirilmesi ile farklı gruplandırmalar yapılmıştır. Gruplandırmalarda panel eğim açılarındaki elektrik üretim verimleri karşılaştırılmıştır. Karşılaştırma sonucunda; 31,7'lik eğim açısına göre 8'li gruplandırmada $129 \mathrm{MWh}$ ve \%5,24 oran ile verimde en yüksek, 2'li gruplandırmada ise $95 \mathrm{MWh}$ ve \%3,86 oran ile verimde en düşük artışın olduğu tespit edilmiştir.

Anahtar Kelimeler: Güneş Enerjisi, Güneş Paneli, Eğim Açısı Değişimi, PVGIS

\section{Examination of The Changes of Inclination Angle of the Solar Power Plants at Yacht Marina Port Areas in Terms of Electricity Production}

\begin{abstract}
Increase in the world population, growth in industry and developing technology increase the demand for energy consumption. This increase in energy consumption causes climate change. Solar Power Plants (SPP) have an effect that reduces both climate change and our country's dependence on foreign energy. Solar panels are used for electricity generation in SPP. In SPP, it is aimed to benefit from the sun at the highest level. In the literature; There are also studies on the change of angle of the panel slope annually and seasonally. Although SPP is used in many areas of housing and industry, it is not used in yacht marinas. The purpose of this study is to utilize SPP at the maximum level for the electricity needs of a yacht marina. Within the scope of this purpose, it has been analyzed
\end{abstract}


to increase the production efficiency of solar panels by changing the monthly optimum inclination angle of solar panels in the SPP.

For analysis, it has been determined that the electricity requirement of a marina in Fethiye District can be supplied by GES with a power of $1500 \mathrm{~kW}$. In this study, Photovoltaic Geographical Information System (PVGIS) simulation program was used. Likewise, electricity generation of SPP panels was found separately on a monthly basis at optimum inclination angles $\left(0^{\circ}, 8^{\circ}, 13^{\circ}, 19^{\circ}, 24^{\circ}, 31.7^{\circ}, 35^{\circ}, 40^{\circ}, 49^{\circ}, 50^{\circ}, 59\right.$ Different groupings were made by changing the monthly optimum inclination angles 2, 3, 4, 5, 6, 7 and 8 times a year in the panels used in the SPP. Electricity generation efficiencies in panel inclination angles were compared in groupings. As a result of comparison; According to the inclination angle of $31.7^{\circ}$, it has been determined that in 8 grouping, the efficiency is the highest with $129 \mathrm{MWh}$ and 5.24\%, and in the 2-group grouping it has been determined that the lowest increase is $95 \mathrm{MWh}$ and $3.86 \%$.

Keywords: Keyword 1, Solar Energy, Solar Panel, Inclination Angle Change, PVGIS

\section{GIRIS}

Dünyada olduğu gibi ülkemizde de artan nüfus yoğunluğu, büyüyen iş kolları ve sanayi faaliyetleri sonucunda enerji tüketimine olan talep her yıl artış göstermektedir. Bu talep artışı beraberinde elektrik üretimi arzının ve buna bağlı olarak da sera gazı emisyonunun hızla yükselmesine sebep olmaktadır. GES iklim değişikliği ile mücadeleye olan olumlu katkısı ve enerjide dışa bağımlılığı azaltıcı bir etkiye sahiptir. Ayrıca, finansal ve stratejik faydaları değerlendirildiğinde önemli ölçüde enerji tasarrufu sağlayan GES yaygınlaştırılarak elektrik üretiminde kullanılması büyük önem arz etmektedir. $\mathrm{Bu}$ doğrultuda, elektrik üretiminde GES uygulamalarına yöneliş dünyada olduğu gibi ülkemiz çapında da son yıllarda ivme kazanmıştır.

GES'de güneşten günün her saatinde en yüksek seviyede yararlanmak amaçlanmaktadır. Bu hususta güneşin dönüş yönünü takip eden güneş panelleri geliştirilmeye başlanılmıştır. Literatür incelendiğinde; sabit eğimli paneller yerine, eksenel (yatay/dikey) hareket etme kabiliyeti olan panellerin verimiyle ilgili çalışmalar yapılmaya başlanmıştır. Ayrıca, güneş panellerin aylık ve mevsimsel optimum eğim açılarının değişim ile ilgili çalışmalarda yapılmaktadır.

Çalışmalarda, güneş panellerinden elde edilen enerji miktarı; enleme ve panelin yüzey ile yaptı̆̆ eğim açısına göre değişmektedir [1]. Literatürde eğim açısı ile ilgili bölgesel olarak birçok metodoloji geliştirilmiştir. İzmir'de maksimum enerji elde etmek için yapılan çalışmada; güney yönlü güneş panellerin optimum eğim açıları yaz ayları için enlemden $34^{\circ}$ aşağı, kış ayları için enlemden $19^{\circ}$ fazla ve yıllık optimum eğim açısı ise $30,3^{\circ}$ olarak bulunmuştur [2]. Dört farklı şehirde (İstanbul, Ankara, Erzurum, Adana) yapılan çalışmada; optimum eğim açısının Erzurum ilinde $56^{\circ}$ ile Aralık ayında, en düşük açının ise Adana ilinde $12^{\circ}$ ile Haziran ayında gerçekleştiği belirtilmiştir [3]. Aïnmelh M'sila konumu için şebekeye bağlı $1 \mathrm{MWp}$ 'lik bir fotovoltaik sistemin simüle ederek, sabit eğim için PVsyst'i kullanmış, ayrıca mevsimsel eğim ayarlamaları ile sabit eğim ve mevsimsel eğim için enerji verimindeki olası değişiklik performans oranları incelenmiştir [4]. Güney Afrika'da yapılan çalışmada, optimum eğim açısında sabitlenmiş kolektörlerin yataya sabitlenmiş kolektörlere göre \%10 daha fazla 1şınım aldığ görülmüş̧ür [5]. Güneye yönlendirilmiş panellerde $20^{\circ}$ ile $40^{\circ}$ arasındaki eğimler için edilen yıllık toplam 1şınımın yatayda elde edilen 1şınıma göre sapması daha stabildir. Bu eğim aralı̆̆ında maksimum değerden sapma \%1,5 civarındadır [6]. PV panellerin yıl ya da mevsim boyunca sabit eğim açılarıyla yerleştirilmeleri yerine, basit ve ekonomik bir düzenek vasitasıyla ayda bir defa o ayın optimum eğim açısına göre ayarlanarak kullanılmaları tavsiye edilmiştir [7]. Malezya'da beş farklı bölgede yapılan çalışmada, güneş panellerin aylık ve mevsimlik optimum eğim açıları belirlenmiştir. Aylık optimum eğim açılarının değiştirilmesiyle güneş panellerinde \%5,02 ila 7,96 arasında, mevsimlik optimum eğim açılarının değiştirilmesinde ise \%4,11 ila 5,85 arasında verim artışı olduğu belirtilmiştir [8]. Yüreğir ovasında yapılan çalışmada panellerin farklı eğim açılarında $\left(15^{\circ}, 30^{\circ}, 45^{\circ}, 60^{\circ}\right)$ enerji üretimi 
değişimleri anlık, günlük ve aylık ölçümleri yapılmıştır. Yıl boyunca $15^{\circ}$ eğimle konumlandırılması durumunda diğer açılara kıyasla yılın ilk 4 ve son 4 ayı yaklaşık \%7-10 enerji kaybı gerçekleştiği, aynı eğimle konumlandırılan paneller aradaki 4 aylık sürede diğer eğim açılarına göre daha avantaj sağladığı belirtilmiştir [9]. Amerika Birleşik Devletleri'nde yapılan çalışmada yıl boyunca eğim açısını aylık olarak değiştirilen panellerin, sabit panellere göre yıllık ortalama $\% 5$ daha fazla güneş 1şınımı aldığ bulunmuştur [10].

Güneş Enerji Potansiyeli Atlası [11] incelendiğinde; ülkemiz coğrafi konumu itibariyle Ege, Akdeniz, Orta Anadolu ve Güney Doğu Anadolu Bölgelerinin güneş 1şınımı açısından avantajlı olduğu anlaşılmaktadır. Ülkemizde aynı zamanda Ege ve Akdeniz bölgeleri turizm potansiyeli yüksek olan bölgelerdir. Turizmde önemli gelir kalemlerinden biri de yat turizmidir.

Yat turizmi, insanların denizlerde seyahat etmesine imkân sağlayan sektörlerden biridir. Yat limanları ise yatlara güvenli barınma imkânı sunmaktadır. Türkiye'de turizm potansiyelindeki artış miktarına bağlı olarak yat limanlarında da elektrik ihtiyacı artmaktadır. Bu artış yaz aylarında maksimum seviyeye ulaşmakta diğer aylarda ise kademeli olarak düşmektedir. Güneşten elektrik üretimi de yaz aylarında maksimum seviyeye ulaşmaktadır [11]. Ülkemizde birçok sektör, ihtiyaçları olan elektriği GES uygulamaları ile elde etmeye başlamıştır. Türkiye kıyılarında toplamda 24.728 adet yat bağlama kapasitesine sahip 61 adet yat limanı [12] mevcut olmasına rağmen yapılan saha araştırmasında yat limanlarında güneş enerjisinden elektrik üretimi henüz bulunmamaktadır [13]. Ayrıca, yat limanlarının Akdeniz ve Güney Ege bölgelerinde yoğunlaşması ile söz konusu bölgelerin güneş enerji potansiyeli açısından yüksek olması bu bölgeleri ön plana çıkarmaktadır.

Literatürden anlaşılacağı üzere yapılan çalışmalarda daha çok bölgesel optimum eğim açılarının aylık, mevsimsel ve altı aylık durumu incelenmiştir. Ayrıca, yat limanları ihtiyacı olan elektriğin güneşten tedarikine ilişkin literatürde bir boşluğun olduğu tespit edilmiştir. Ülkemizdeki yat limanlarında güneşten su 1sıtmak amacı dışında faydalanılmamaktadır. Bu çalışmanın amacı, güneş enerji potansiyeli fazla olan Akdeniz ve Ege kıyılarındaki yat limanlarının elektrik ihtiyacının GES ile karşılanması için literatüre ve yatırımcılara katkı sağlamaktır. Bunun için panellerdeki aylık optimum eğim açılarının aylık ve mevsimlik yerine yılda birden fazla kez değiştirilmesi ile elde edilen sonuçlar analiz edilmiştir.

\section{MATERYAL METOD}

Dünya yüzeyine gelen güneş radyasyonunu tahmin etmek için simülasyon programları araştırmacılar tarafından kullanılmaktadır. Bu gelişmiş programlar sayesindeki çalışmalar ile gerçeğe yakın analizlerin yapılması kolaylaşmaktadır. PVGIS; Avrupa Birliği tarafından geliştirilen ve meteorolojik verileri kullanarak güneş 1şınımından elde edilebilecek elektrik enerjisini hesaplamaktadır. Bu simülasyon programı kullanıcılarına ücretsiz olarak sunulmaktadır. PVGIS; uygulama alanı koordinatlarına göre günlük, aylık ve yıllık optimum 1şınım değerleri ve üretilecek olan elektrik üretim miktarı hesaplanabilmektedir.

PVGIS simülasyon programı güneş 1şınım ve panel sıcaklığının etkilerini kullanarak hesaplama yapmaktadır. Güç $P[\mathrm{~W}]$; güneş 1şınımı ve panel sıcaklığına bağlı olarak Eşitlik (1-4) ile hesaplanmaktadır $[14,15]$.

$$
\begin{aligned}
& P\left(G_{T}{ }^{\prime}, T^{\prime}\right)=G_{T}{ }^{\prime}\left(P_{S T C, m}+k_{1} \operatorname{In}\left(G_{T}{ }^{\prime}\right)+k_{2} \operatorname{In}\left(G_{T}{ }^{\prime}\right)^{2}+k_{3} T^{\prime}+k_{4} T^{\prime} \operatorname{In}\left(G_{T}{ }^{\prime}\right)+\right. \\
& \left.k_{5} T^{\prime} \operatorname{In}\left(G_{T}{ }^{\prime}\right)^{2}+k_{6} T^{\prime 2}\right) \\
& G_{T}{ }^{\prime} \equiv G_{T} / G_{S T C}
\end{aligned}
$$




$$
\begin{aligned}
& T^{\prime} \equiv T_{\text {mod }}-T_{S T C} \\
& \eta_{\text {rel }}\left(G_{T}{ }^{\prime}, \mathrm{T}^{\prime}\right) \equiv \mathrm{P}\left(G_{T}{ }^{\prime}, \mathrm{T}^{\prime}\right) / \mathrm{P}_{\mathrm{STC}, \mathrm{m}} G_{T}{ }^{\prime}
\end{aligned}
$$

Burada, $G_{T}{ }^{\prime}$ toplam güneş 1şınımı ve $T^{\prime}$ panel sıcaklı̆ $1\left[{ }^{\circ} \mathrm{C}\right]$ normalize edilerek verilmiştir. $k_{1}$ 'den $k_{6}$ 'ya kadar olan katsayılar PV paneli cinsine özgü Avrupa Güneş Test Kurulumu (ESTI) tarafından ölçülen verilere bağlı değerlerdir. $P_{S T C, m}$ Standart Test Koşullarındaki (STC) maksimum gücü [W] ifade etmektedir [15].

Ayrıca, Eşitlik (1-4)'de, $T_{\text {mod }}$ panel sıcaklığ $\left[{ }^{\circ} \mathrm{C}\right], \mathrm{STC}$ 'de $G_{S T C}=1000\left[\mathrm{~W} / \mathrm{m}^{2}\right], T_{S T C}=25\left[{ }^{\circ} \mathrm{C}\right] \mathrm{ve}$ $\eta_{\text {rel }}$ ise verimliliği belirtmektedir.

Çalışma kapsamında PVGIS programda;

- GES'de kullanılan panel azimut açısı güney $\left(0^{\circ}\right)$

- Panel malzemesi kristal silikon

- Sistem kayb1 \%14

- Sistem şebekeye (on grid) bağli

- Güneş panellerinin kurulumunun yapılacağı alan işletmenin kendi tasarrufunda

- Tesiste trafo merkezinin işletmenin kendi tasarrufunda altında

olduğu kabul edilmiştir. Ayrıca çalışmada, güneş ışınımı verileri yerine GES çıktısı olan elektrik enerjisi [MWh] verileri kullanılmıştır.

PVGIS programı yardımıyla önceki çalışmada [13] söz konusu yat limanında $1500 \mathrm{~kW}$ kurulu güce sahip olan GES'in güneş paneli optimum eğim açısı $31,7^{\circ}$ 'de yıllık $2.462 \mathrm{MWh}$ elektrik üretimi ile maksimum verime ulaştığı görülmüş olup yat limanı ihtiyacını karşılayabileceği tespit edilmiştir.

Bu çalışmada yat limanı elektrik ihtiyacını karşılayacak olan GES'de kullanılan $1500 \mathrm{~kW}$ kurulu güce sahip güneş panellerinde herhangi bir değişiklik yapılmadan, sadece her ay/aylar güneş panel eğim açısının değiştirilmesinin GES verimine etkisi analiz edilmiştir. Bu işlem GES imalatı esnasında basit bir aparat yardımıyla gerçekleştirilebilmektedir. PVGIS programında güneş paneli optimum eğim açısının aylık bazda $8^{\circ}, 13^{\circ}, 19^{\circ}, 24^{\circ}, 31,7^{\circ}, 35^{\circ}, 40^{\circ}, 49^{\circ}, 50^{\circ}, 59^{\circ}$ açılarda en yüksek elektrik üretimi değerleri ayrı ayrı bulunmuştur.

Örnek olarak Fethiye ilçesinde Şubat ayı için panel optimum eğim açısının tespiti için farklı eğim açılarında GES' den elde edilen elektrik üretim miktarı PVGIS programı ile hesaplanmış olup, Şekil 1'de verilmiştir. Hesaplamalar neticesinde çıkan verilerden $49^{\circ}$ ve $50^{\circ}$ eğim açısı için en yüksek GES elektrik üretim miktarı (148 MWh) elde edilmiştir. En yüksek elde edilen elektrik üretim miktarı $49^{\circ}$ ve $50^{\circ}$ olan bu eğim açıları, Şubat ayına ait optimum eğim açısı olarak belirlenmiştir. 


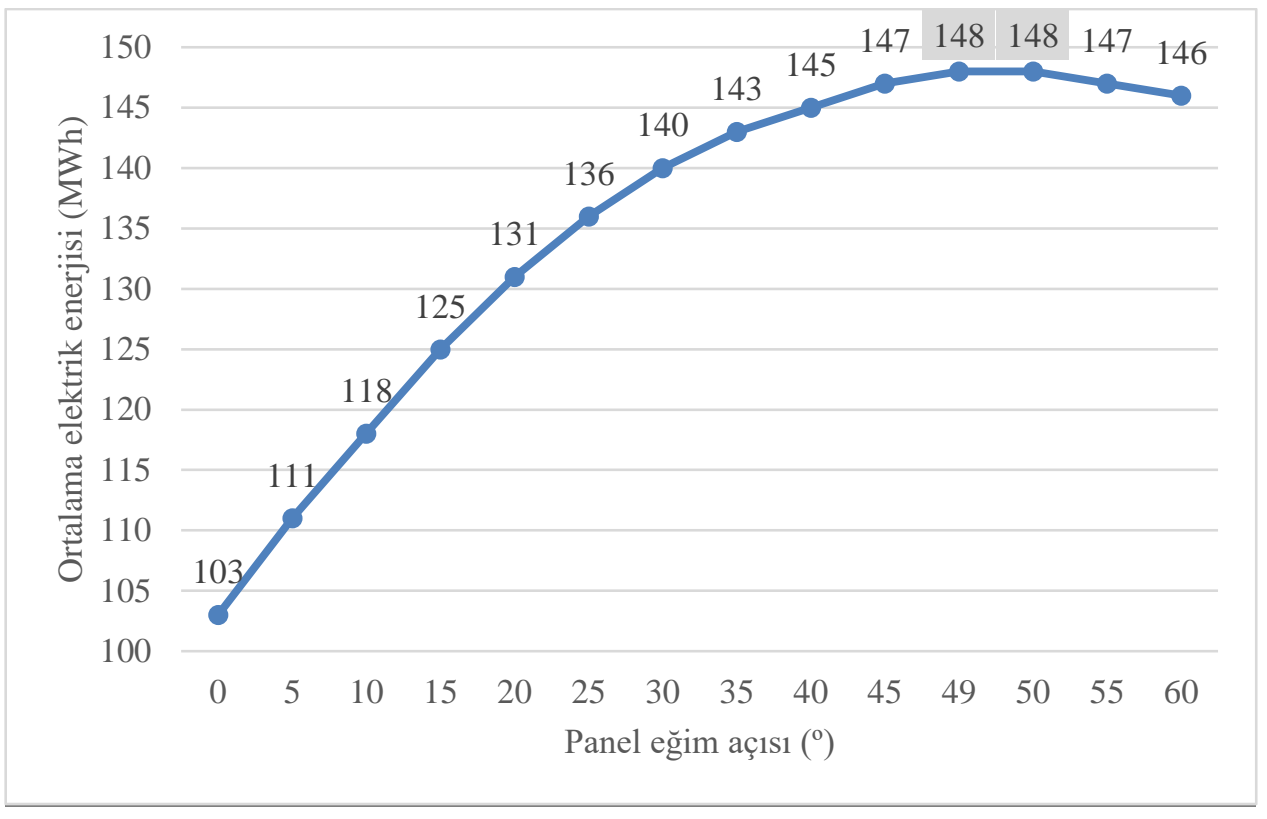

Şekil 1. Şubat ayı için optimum eğim açısının belirlenmesi

Güneş panel eğim açısının yılda birden fazla kez farklı aylarda değişmesi durumu kombine edilerek gruplandırma yapılmıştır. Elektrik üretim değerleri farklı sayıda gruplandırma ile GES veriminin artırılması amaçlanmıştır. Bu amaca yönelik PVGIS hesaplama sonucunda aylık gruplandırma şekli Tablo 1'de ayrıntılı olarak verilmiştir. Her bir grubun karşında yılda kaç kez ve hangi aylarda farklı değişim grubunda olması gerektiği belirtilmiş̧tir. Akabinde panelin eğim açısının yılda 2, 3, 4, 5, 6, 7 ve 8 defa değiştirilmesi durumunda elektrik üretimindeki artış miktarı ayrı ayrı hesaplanmıştır. Hesaplamalar ile güneş panelinin maksimum elektrik üretimi için hangi gruplarda daha verimli olduğu karşılaştırılmıştır.

Tablo 1. GES panelinde aylara göre gruplandırma

\begin{tabular}{|c|c|c|c|c|c|c|c|c|c|}
\hline Gruplar & $\begin{array}{l}\text { Yıldaki } \\
\text { değişim } \\
\text { miktarı }\end{array}$ & $\begin{array}{c}1 . \\
\text { değişim } \\
\text { grubu }\end{array}$ & $\begin{array}{c}2 . \\
\text { değişim } \\
\text { grubu }\end{array}$ & $\begin{array}{c}3 . \\
\text { değişim } \\
\text { grubu }\end{array}$ & $\begin{array}{c}4 . \\
\text { değişim } \\
\text { grubu }\end{array}$ & $\begin{array}{c}5 . \\
\text { değişim } \\
\text { grubu }\end{array}$ & $\begin{array}{c}\text { 6. } \\
\text { değişim } \\
\text { grubu }\end{array}$ & $\begin{array}{c}7 . \\
\text { değişim } \\
\text { grubu }\end{array}$ & $\begin{array}{c}\text { 8. } \\
\text { değişim } \\
\text { grubu }\end{array}$ \\
\hline $\begin{array}{c}\text { 2'li } \\
\text { gruplandırma }\end{array}$ & $\begin{array}{l}\text { Yilda } 2 \\
\text { defa } \\
\text { değişim }\end{array}$ & $\begin{array}{l}\text { Ocak, } \\
\text { Şubat, } \\
\text { Mart, } \\
\text { Ekim, } \\
\text { Kasım, } \\
\text { Aralık }\end{array}$ & $\begin{array}{c}\text { Nisan, } \\
\text { Mayıs, } \\
\text { Haziran, } \\
\text { Temmuz, } \\
\text { Ağustos, } \\
\text { Eylül }\end{array}$ & - & - & - & - & - & - \\
\hline $\begin{array}{c}\text { 3'lü } \\
\text { gruplandırma }\end{array}$ & $\begin{array}{c}\text { Yilda } 3 \\
\text { defa } \\
\text { değişim }\end{array}$ & $\begin{array}{l}\text { Ocak, } \\
\text { Şubat, } \\
\text { Mart, } \\
\text { Ekim, } \\
\text { Kasım, } \\
\text { Aralık }\end{array}$ & $\begin{array}{c}\text { Nisan, } \\
\text { Mayis, } \\
\text { Haziran, } \\
\text { Temmuz, } \\
\text { Ağustos }\end{array}$ & Eylül & - & - & - & - & - \\
\hline $\begin{array}{l}\text { 4'lü } \\
\text { gruplandırma }\end{array}$ & $\begin{array}{c}\text { Yilda } 4 \\
\text { defa } \\
\text { değişim }\end{array}$ & $\begin{array}{c}\text { Ocak, } \\
\text { Şubat, } \\
\text { Ekim, } \\
\text { Kasım, } \\
\text { Aralık }\end{array}$ & $\begin{array}{c}\text { Nisan, } \\
\text { Mayıs, } \\
\text { Haziran, } \\
\text { Temmuz, } \\
\text { Ağustos }\end{array}$ & Eylül & Mart & - & - & - & - \\
\hline $\begin{array}{c}\text { 5'li } \\
\text { gruplandırma }\end{array}$ & $\begin{array}{l}\text { Yilda } 5 \\
\text { defa } \\
\text { değişim }\end{array}$ & $\begin{array}{l}\text { Ocak, } \\
\text { Şubat, } \\
\text { Ekim, } \\
\text { Kasım, } \\
\text { Aralık }\end{array}$ & $\begin{array}{c}\text { Mayis, } \\
\text { Haziran, } \\
\text { Temmuz, } \\
\text { Ağustos }\end{array}$ & Eylül & Mart & Nisan & - & - & - \\
\hline
\end{tabular}




\begin{tabular}{|c|c|c|c|c|c|c|c|c|c|}
\hline $\begin{array}{l}\text { 6'l1 } \\
\text { gruplandırma }\end{array}$ & $\begin{array}{l}\text { Yılda } 6 \\
\text { defa } \\
\text { değişim }\end{array}$ & $\begin{array}{l}\text { Ocak, } \\
\text { Şubat, } \\
\text { Ekim, } \\
\text { Kasım, } \\
\text { Aralık }\end{array}$ & $\begin{array}{l}\text { Mayis, } \\
\text { Haziran, } \\
\text { Temmuz }\end{array}$ & Ağustos & Eylül & Mart & Nisan & - & - \\
\hline $\begin{array}{c}\text { 7'li } \\
\text { gruplandırma }\end{array}$ & $\begin{array}{l}\text { Y1lda } 7 \\
\text { defa } \\
\text { değişim }\end{array}$ & $\begin{array}{l}\text { Ocak, } \\
\text { Şubat, } \\
\text { Kasım, } \\
\text { Aralık }\end{array}$ & $\begin{array}{l}\text { Mayis, } \\
\text { Haziran, } \\
\text { Temmuz }\end{array}$ & Ağustos & Eylül & Ekim & Mart & Nisan & - \\
\hline $\begin{array}{l}\text { 8'li } \\
\text { gruplandırma }\end{array}$ & $\begin{array}{c}\text { Yilda } 8 \\
\text { defa } \\
\text { değişim }\end{array}$ & $\begin{array}{l}\text { Ocak, } \\
\text { Kasım, } \\
\text { Aralık }\end{array}$ & $\begin{array}{c}\text { Mayis, } \\
\text { Haziran, } \\
\text { Temmuz }\end{array}$ & Ağustos & Eylül & Ekim & Şubat & Mart & Nisan \\
\hline
\end{tabular}

\section{BULGULAR VE TARTIȘM}

Güneş 1şığı; güneş panellerinin üzerine dik açıyla düştüğü sürece elektrik üretimi artış göstermektedir. Güneşi takip ederek güneş ışınlarının sürekli olarak dik alınmasını sağlayan sistemler geliştirilmektedir [16]. Yat limanının elektrik ihtiyacının GES'den karşılanması için PVGIS simülasyon programı kullanılarak elde edilen elektrik enerjisi miktarı Tablo 2 görülmektedir. Tablo 2 incelendiğinde, yıllık optimum eğim açısı $31,7^{\circ}$ ile GES elektrik üretiminin $2462 \mathrm{kWh}$ ile maksimum değere ulaştığ görülmektedir [13].

Tablo 2. GES panel optimum eğim açıları ve aylık üretilen elektrik miktarları (MWh) [14]

\begin{tabular}{ccccccccccc}
\hline $\begin{array}{c}\text { Panel eğim } \\
\text { açısı }\end{array}$ & $8^{\circ}$ & $13^{\circ}$ & $19^{\circ}$ & $24^{\circ}$ & $31,7^{\circ}$ & $35^{\circ}$ & $40^{\circ}$ & $49^{\circ}$ & $50^{\circ}$ & $59^{\circ}$ \\
\hline Ocak & 103 & 112 & 123 & 130 & 140 & 143 & 147 & 153 & 153 & 155 \\
\hline Şubat & 115 & 122 & 130 & 135 & 141 & 143 & 145 & 148 & 148 & 146 \\
\hline Mart & 182 & 189 & 196 & 200 & 204 & 205 & 206 & 204 & 203 & 197 \\
\hline Nisan & 222 & 226 & 228 & 229 & 227 & 226 & 222 & 213 & 211 & 197 \\
\hline Mayıs & 255 & 255 & 253 & 250 & 243 & 239 & 231 & 215 & 213 & 191 \\
\hline Haziran & 273 & 271 & 266 & 261 & 250 & 244 & 234 & 213 & 210 & 183 \\
\hline Temmuz & 283 & 282 & 278 & 273 & 263 & 257 & 248 & 227 & 224 & 197 \\
\hline Ăgustos & 263 & 266 & 267 & 266 & 263 & 259 & 253 & 239 & 237 & 217 \\
\hline Eylül & 216 & 223 & 229 & 233 & 236 & 237 & 236 & 231 & 230 & 220 \\
\hline Ekim & 164 & 173 & 183 & 190 & 198 & 200 & 203 & 205 & 205 & 203 \\
\hline Kasım & 121 & 132 & 143 & 152 & 162 & 166 & 171 & 177 & 177 & 179 \\
\hline Aralık & 96 & 106 & 117 & 124 & 135 & 139 & 144 & 150 & 151 & 154 \\
\hline Toplam & 2293 & 2357 & 2413 & 2443 & 2462 & 2458 & 2440 & 2375 & 2362 & 2239 \\
\hline elektrik üretimi & 0,93 & 0,96 & 0,98 & 0,99 & 1,00 & 1,00 & 0,99 & 0,96 & 0,96 & 0,91 \\
\hline Eao / Eyo & & & & & & & & & \\
\hline
\end{tabular}

Tablo 2'de; gri renkli olan sütun daha önceki çalışmada [13] yıllık sabit bir eğim açısı ile elde edilen elektrik üretim miktarıdır. Ayrıca, her ay için optimum eğim açısındaki elde edilen maksimum elektrik üretimi sarı renkle belirtilmiştir. Sarı renklerde, örneğin $31,7^{\circ}$ 'de Ocak ayında $140 \mathrm{MWh}$ üretim gerçekleşirken $59^{\circ}$ eğimde $155 \mathrm{MWh}$ 'e ulaşmaktadır. Bu durum panel eğim açısının $59^{\circ}$ 'ye getirilmesi durumunda verimin artacağına ilişkin bir göstergedir. Ayrıca, panelin Ocak, Kasım ve Aralık aylarında $59^{\circ}$ 'ye getirilmesi ile üretilen elektriğin maksimum seviyede olması bir grup olarak değerlendirilmiştir. Ayrıca yatay yönde yakınsama durumu dikkate alınarak diğer aylarda aynı şekilde gruplandırmaya dahil edilmiş̧ir. Tablo 2'deki Eyo=2462 MWh olup 31,7'deki yıllık optimum eğim açısındaki elektrik 
üretimini, Eao [MWh] ise her bir açıdaki toplam elektrik üretimini, Eao / Eyo ise eğim açısına bağlı verim oranını belirtmektedir

Tablo 2 incelendiğinde bazı açı ve aylarda maksimum değer eşit çıkmıştır Çalışmada bu durum dikkate alınmıştır. Fethiye ilçesi için optimum eğim açısı $59^{\circ}$ ile Ocak, Kasım ve Aralık ayında en yüksek, $8^{\circ}$ ile Mayıs, Haziran ve Temmuz ayında en düşük değerde maksimum elektrik üretimi gerçekleşecektir.

GES'de kullanılan güneş enerji panelleri eğim açıları yılda 2, 3, 4, 5, 6, 7, ve 8 defa değiștirilecek șekilde farklı aylarda kombinasyon oluşturularak gruplandırma yapılmıştır. $\mathrm{Bu}$ gruplandırma işleminde maksimum üretim değerleri elde edilecek şekilde sağdan ve soldan yakınsama olacak şekilde hesaplanma yapılmıştır. Aylara göre gruplandırma işleminde kullanılan açılar ve ait oldukları aylar ayrıntılı bir şekilde; Şekil 2, Şekil 3, Şekil 4, Şekil 5, Şekil 6, Şekil 7 ve Şekil 8'de gösterilmiştir.

Şekil 2'de görüldüğü üzere açının yılda 8 defa (8'li grup); $8^{\circ}$ (Mayıs, Haziran, Temmuz), $19^{\circ}$ (Ağustos), $24^{\circ}$ (Nisan), $35^{\circ}$ (Eylül), $40^{\circ}$ (Mart), $49^{\circ}$ (Ekim), 50 (Şubat) ve 59 (Ocak, Kasım, Aralık) olmak üzere sekiz farklı kombineden oluşmaktadır. GES'de bu durumda maksimum elektrik üretimi gerçekleşmektedir.

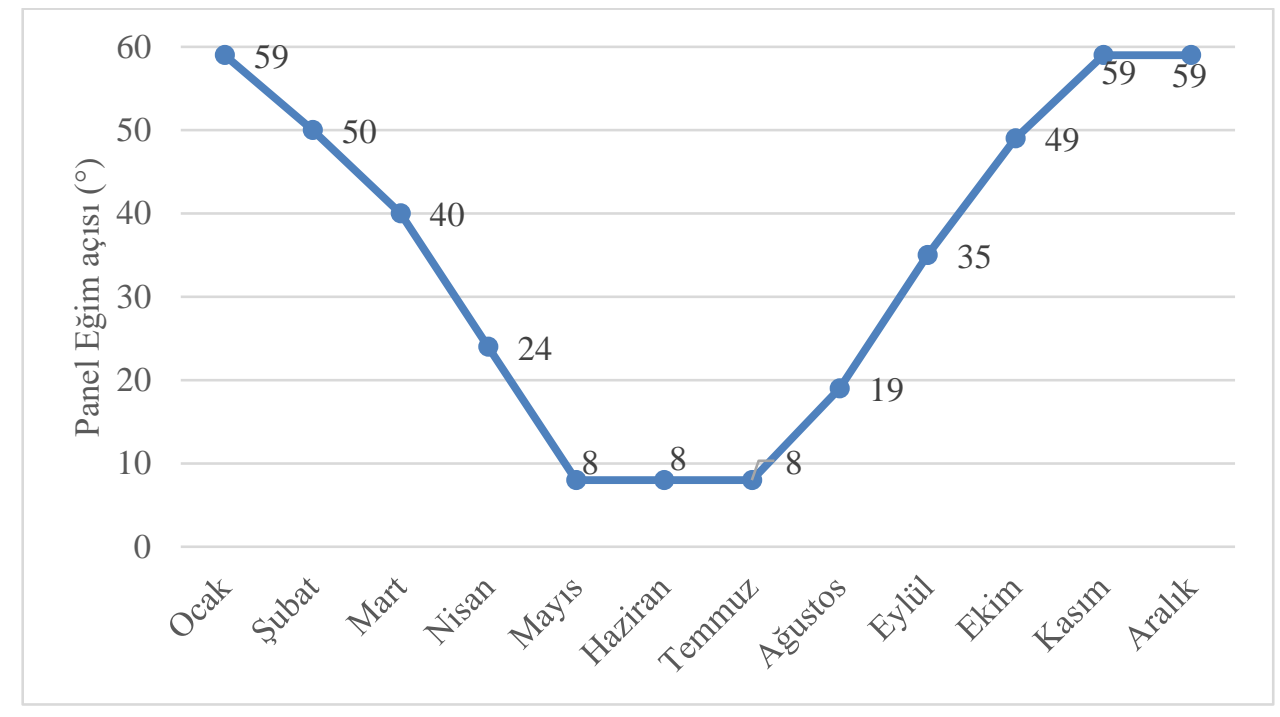

Şeki1 2. Güneş paneli optimum ĕgim açılarının 8'li gruplandırmada aylara göre dă̆ılımı

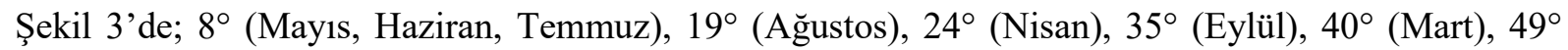
(Ekim) ve $59^{\circ}$ (Ocak, Şubat, Kasım, Aralık) olmak üzere yedi farklı kombineden oluştuğu durum verilmiştir. Şekil 2 ve Şekil 3'de birlikte incelendiğinde $50^{\circ}$ 'lik açı en yakın $59^{\circ}$ 'lik açı ile yakınsadığında verimin maksimum olduğu görülmüştür. 


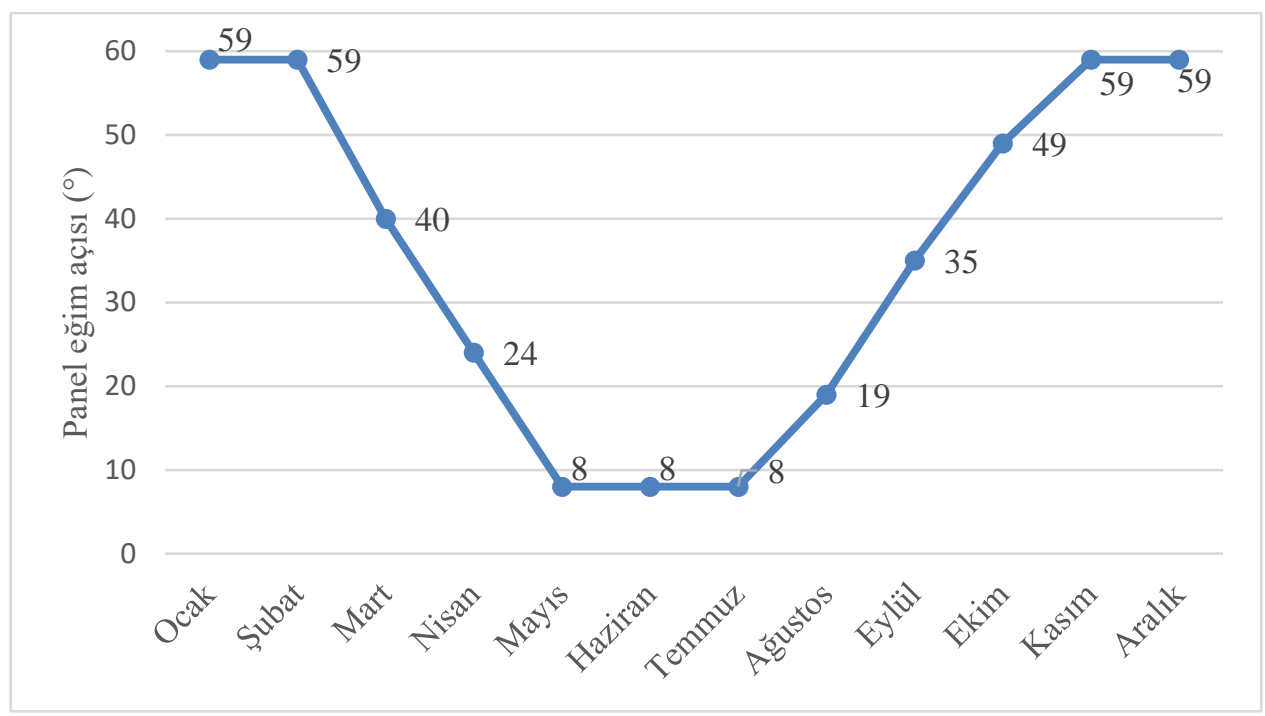

Şeki1 3. Güneş paneli optimum eğim açılarının 7'li gruplandırmada aylara göre dağılımı

Şekil 4'de açının yılda 6 defa değişim ile $8^{\circ}$ (Mayıs, Haziran, Temmuz), $19^{\circ}$ (Ağustos), $24^{\circ}$ (Nisan), $35^{\circ}$ (Eylül), $40^{\circ}$ (Mart) ve 59 (Ocak, Şubat, Ekim, Kasım, Aralık) olmak üzere altı farklı kombineden oluştuğu görülmektedir. Şekil 3 ve Şekil 4 incelendiğinde $49^{\circ}$ 'lik açı en yakın $59^{\circ}$ 'lik açı ile yakınsadığında 6'lı gruplar içerisinde en yüksek elektrik üretimi gerçekleşmiştir.

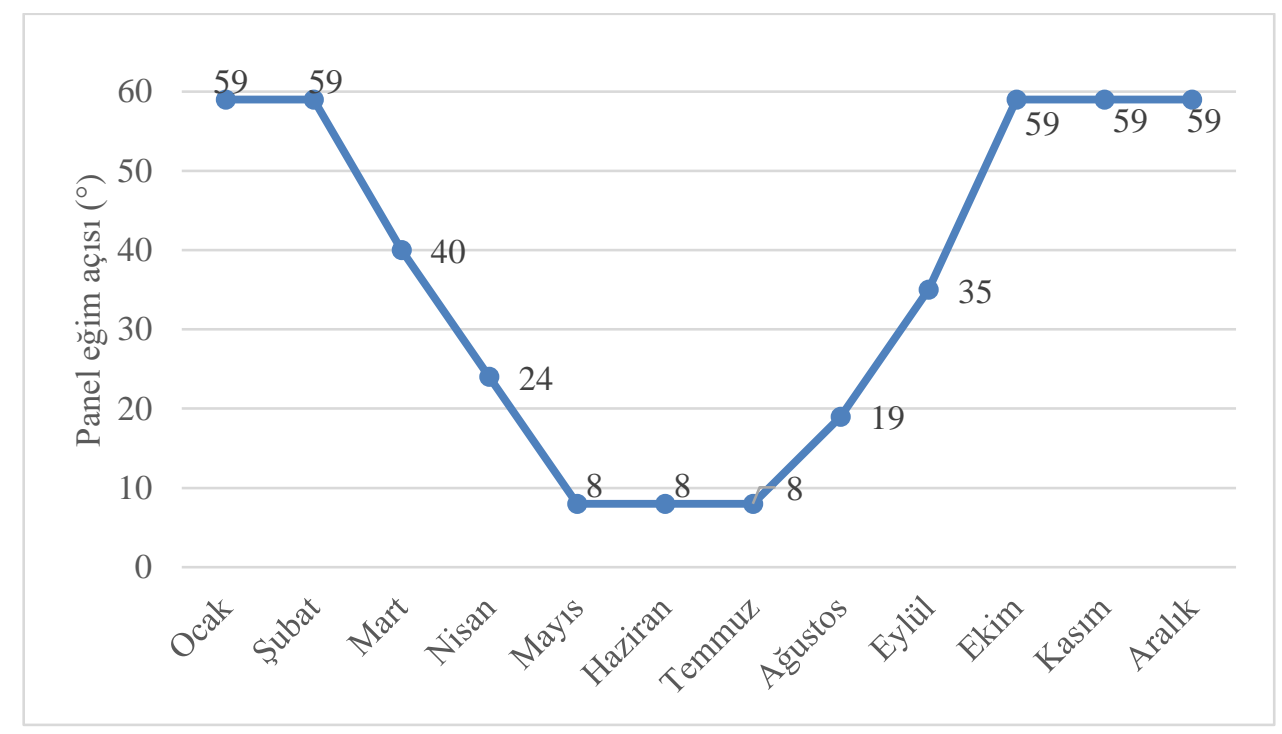

Şeki1 4. Güneş paneli optimum eğim açılarının 6’lı gruplandırmada aylara göre dağılımı

Şekil 5'de açının yılda 5 defa değişimi (5'ligrup); $8^{\circ}$ (Mayıs, Haziran, Temmuz, Ağustos), $24^{\circ}$ (Nisan), $35^{\circ}$ (Eylül), $40^{\circ}$ (Mart) ve 59 (Ocak, Șubat, Ekim, Kasım, Aralık) olmak üzere beș farklı kombineden oluşmaktadır. Şekil 4 ve Şekil 5'de görüldüğü üzere $19^{\circ}$ 'lik açı en yakın $8^{\circ}$ 'lik açı ile yakınsamakta olup 5'li gruplar içerisinde en yüksek verim elde edilmiştir. 


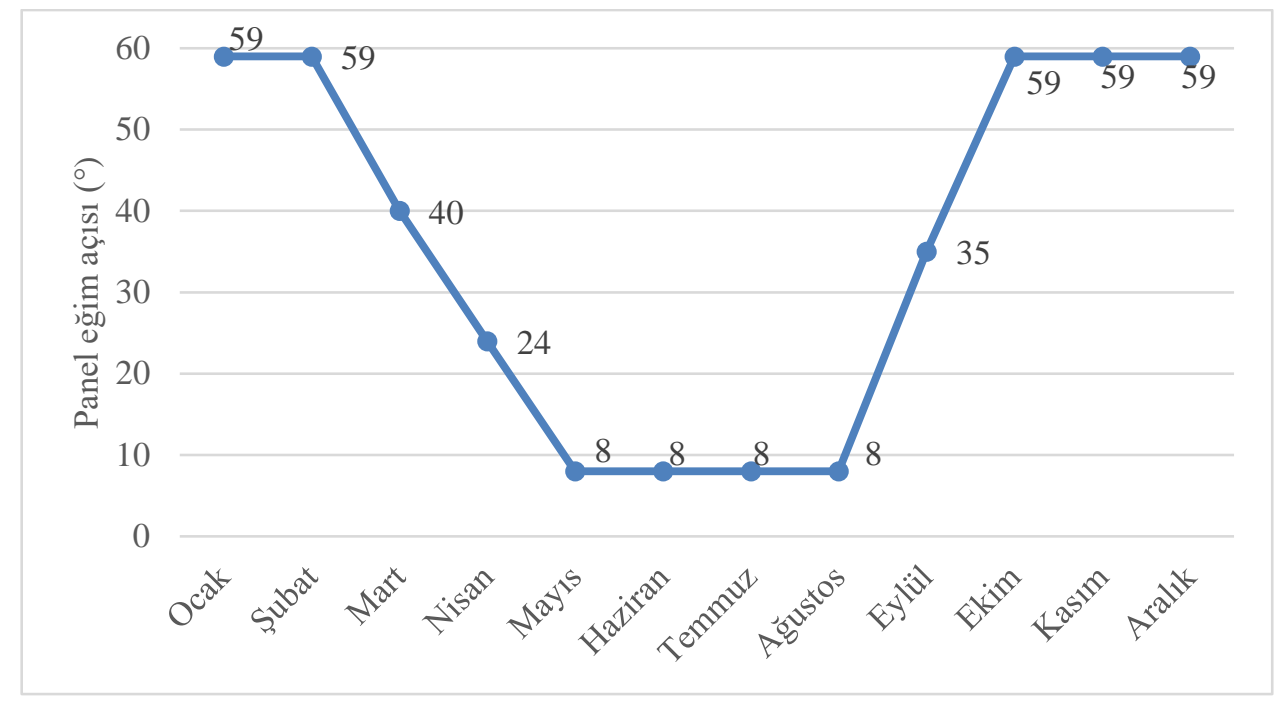

Şeki1 5. Güneş paneli optimum eğim açılarının 5 'li gruplandırmada aylara göre dă̆ılımı

Şekil 6' da görüldüğg̈ üzere; $13^{\circ}$ (Nisan, Mayıs, Haziran, Temmuz, Ağustos), $35^{\circ}$ (Eylül), $40^{\circ}$ (Mart) ve $59^{\circ}$ (Ocak, Şubat, Ekim, Kasım, Aralık) olmak üzere dört farklı kombineden oluşmaktadır. Şekil 5 ve Şekil 6'de birlikte incelendiğinde; 4'lü gruplandırmada $24^{\circ}$ ve $8^{\circ}$ 'lik açıların en yakın $13^{\circ}$ 'lik açı ile değişmesi durumunda verim maksimum değere ulaşmıştır.

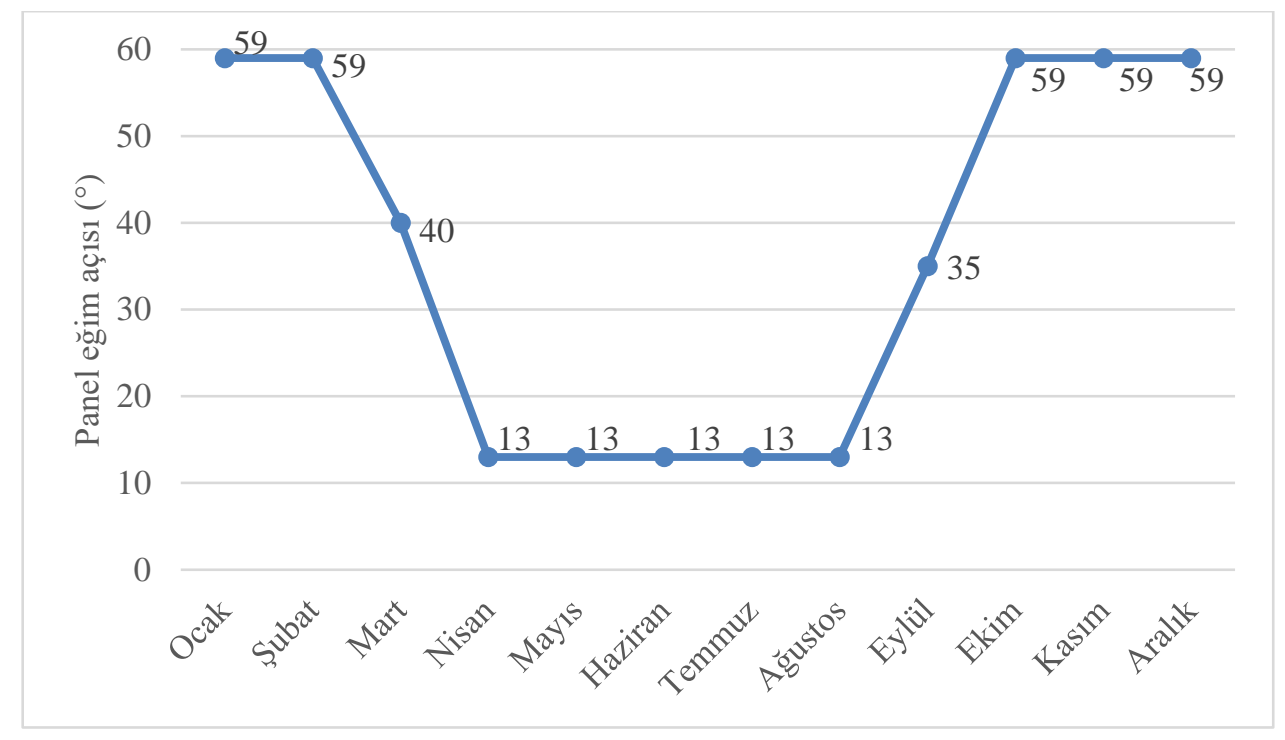

Şeki1 6. Güneş paneli optimum eğim açılarının 4'lü gruplandırmada aylara göre dağılımı

Şekil 7'de; $13^{\circ}$ (Nisan, Mayıs, Haziran, Temmuz, Ağustos), 35 (Eylül) ve $59^{\circ}$ (Ocak, Şubat, Mart, Ekim, Kasım, Aralık) olmak üzere üç farklı kombineden oluştuğu görülmektedir. Şekil 6 ve Şekil 7'de görüldüğü üzere Yılda 3 defa açı değişimi durumunda $40^{\circ}$ 'lik açının en yakın $13^{\circ}$ 'lik açı ile yakınsadığı ve verimin maksimum değere ulaştığ 1 görülmüștür 


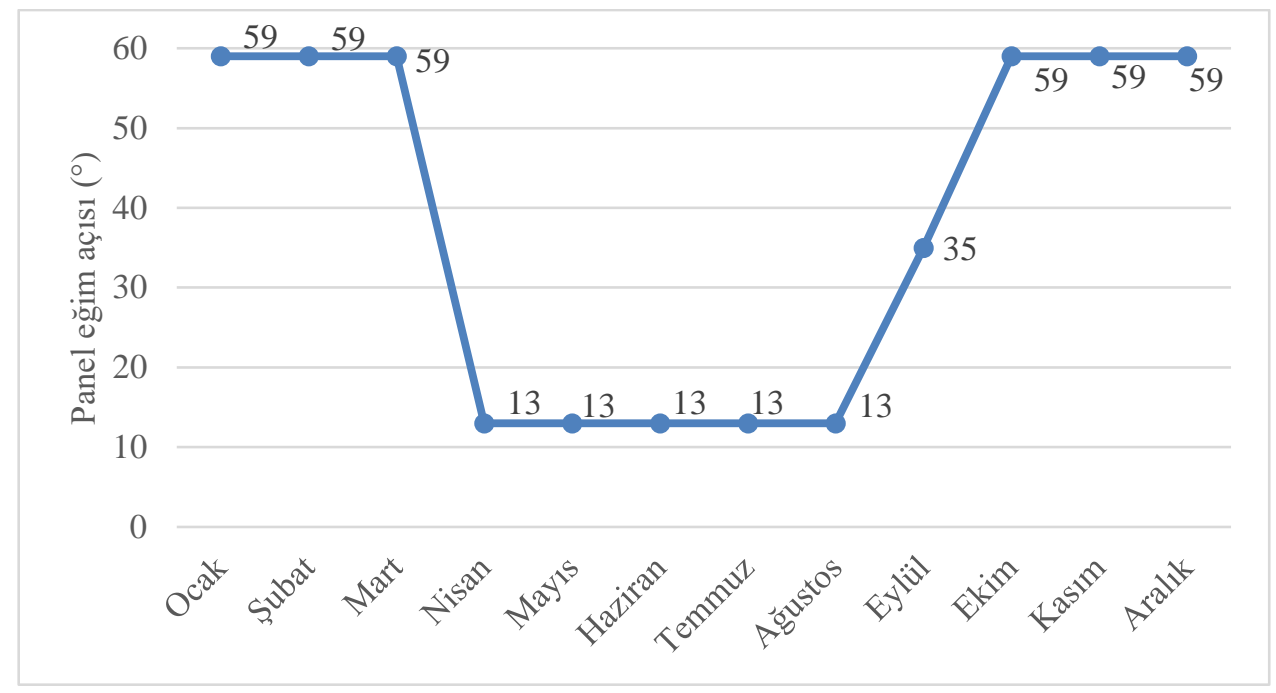

Şeki1 7. Güneş paneli optimum eğim açılarının 3 'lü gruplandırmada aylara göre dă̆ılımı

Şekil 8'de açının yılda 2 defa değişimi; $13^{\circ}$ (Nisan, Mayıs, Haziran, Temmuz, Ağustos, Eylül) ve 59 (Ocak, Şubat, Mart, Ekim, Kasım, Aralık) olmak üzere iki farklı kombineden oluşmaktadır. Şekil 7 ve Şekil 8 beraber incelendiğinde $35^{\circ}$ 'lik açının en yakın $13^{\circ}$ 'lik açı ile yakınsamıştır. $2^{\prime}$ 'li gruplandırmalar arasında verim en yüksek değere ulaşmıştır.

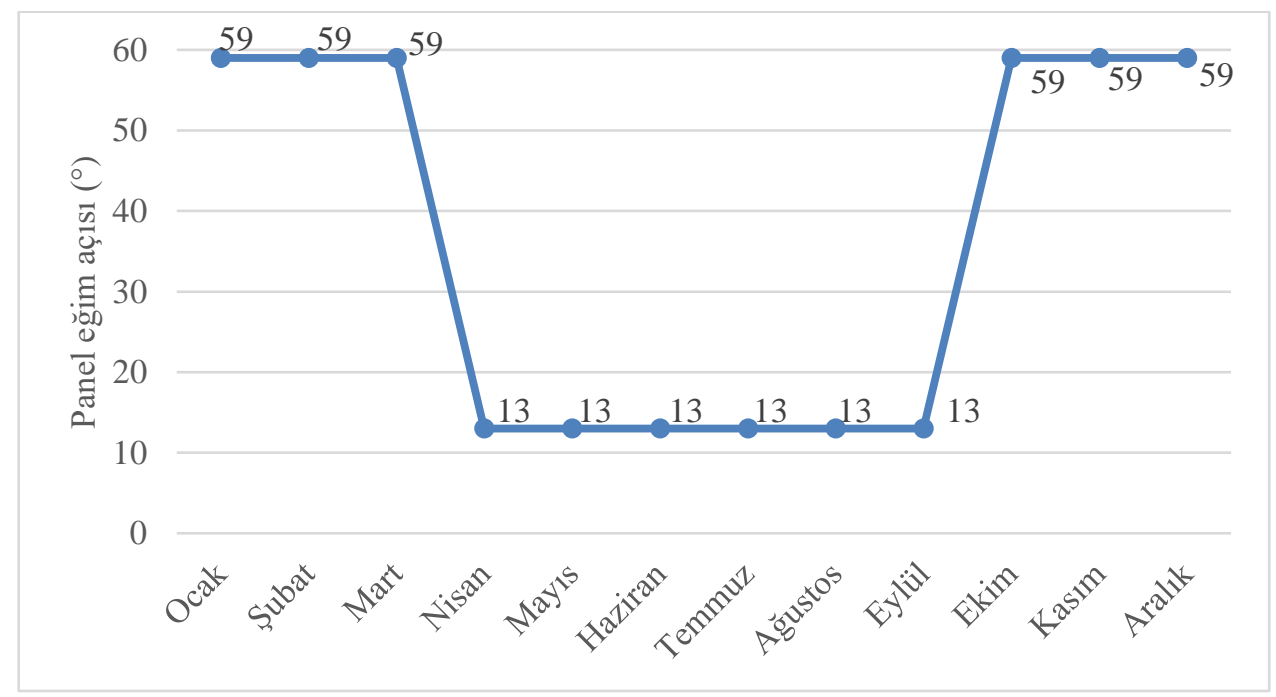

Şeki1 8. Güneş paneli optimum eğim açılarının 2'li gruplandırmada aylara göre dağıllımı

Bahse konu şekillerde; Mayıs, Haziran ve Temmuz aylarında üretimin eşit olması nedeniyle aylık güneş paneli optimum eğim açısının değiştirilmeyeceği, Kasım, Aralık ve Ocak aylarında da aynı durumun söz konusu olduğu tespit edilmiştir. Bu durum gruplandırma sayısının azalmasına neden olmuştur. Şekil 9'da, güneş panel eğim açısı değişim grup sayısı ile verim arasındaki ilişki görülmektedir. Güneş panel eğim açısındaki gruplandırmada 9, 10, 11 ve 12'li gruplandırmada verimde bir artışın olmadığı görülmektedir. Aynı şekilde hesaplamalarda bahse konu dört değişim sonucunda GES'den elde edilecek olan elektrik üretiminde herhangi bir artışın olmayacağı tespit edilmiştir. Dolayısıyla, 9, 10, 11 ve 12'li gruplandırmalar değerlendirmeye alınmamıştır. 


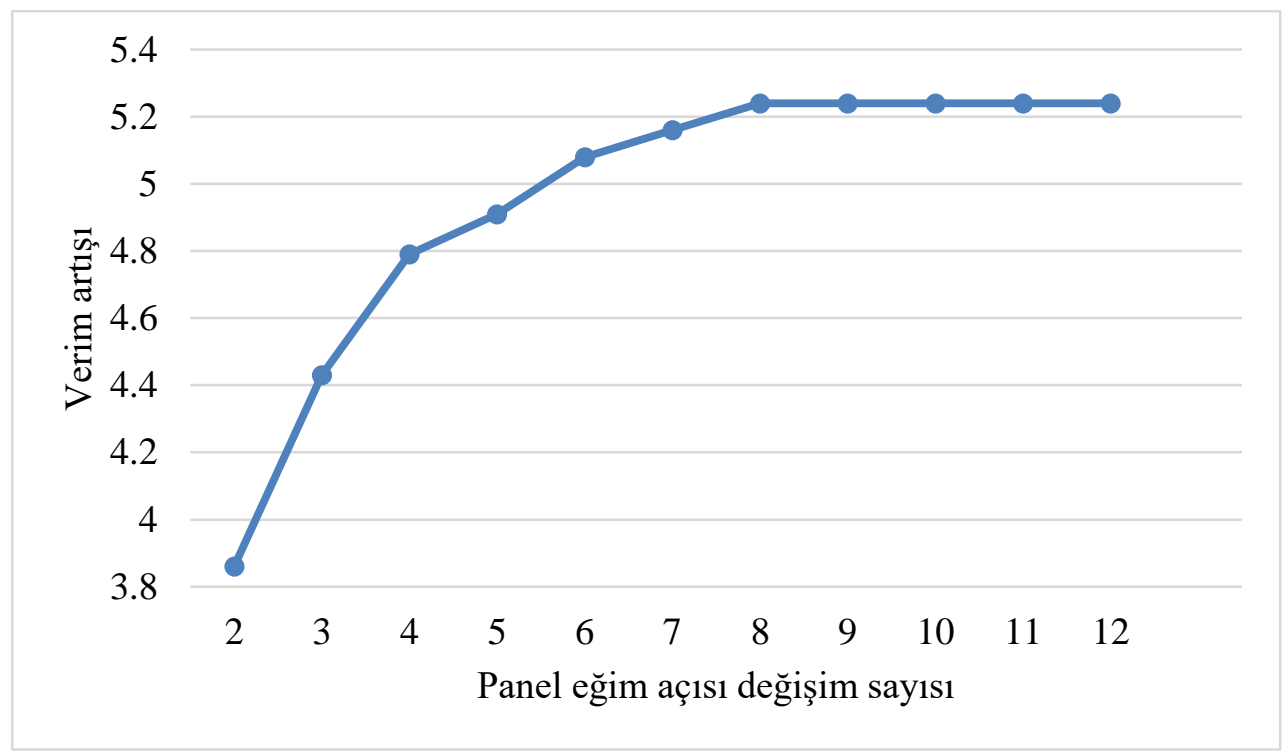

Şekil 9. Gruplandırma sayısı ile verim arasındaki ilişki

Aylık optimum güneş panel eğim açısındaki değişimi ile yapılan gruplandırmada üretilen elektrik miktarı Tablo 3'de görülmektedir. Ayrıca Tablo 3'de güneş panelinin yatay $\left(0^{\circ}\right)$ ve yıllık optimum eğim açıs1 $\left(31,7^{\circ}\right)$ konumunda üretilen elektrik miktarları ile verim sonuçları verilmiştir. Tablo 3'de görüldüğü üzere, güneş panel eğim açısı değişim sayısı arttıkça GES'den elde edilen elektrik üretiminde de bir artış olduğu görülmüştür. Bu artış miktarı yılda; 2'li gruplandırmada en düşük seviyede, 8'li gruplandırmada ise en yüksek seviyede gerçekleşmiştir.

Tablo 3. GES panel eğim açı grupları değişimindeki verim artışı (MWh) [12]

\begin{tabular}{|c|c|c|c|c|c|c|c|c|c|}
\hline $\begin{array}{l}\text { Aylar/ } \\
\text { Gruplar }\end{array}$ & $\begin{array}{c}2 ' l i \\
\text { grup }\end{array}$ & $\begin{array}{l}\text { 3'li } \\
\text { grup }\end{array}$ & $\begin{array}{c}\text { 4'li } \\
\text { grup }\end{array}$ & $\begin{array}{l}5 \text { 'li } \\
\text { grup }\end{array}$ & $\begin{array}{l}\text { 6'li } \\
\text { grup }\end{array}$ & $\begin{array}{c}\text { 7'li } \\
\text { grup }\end{array}$ & $\begin{array}{c}\text { 8'li } \\
\text { grup }\end{array}$ & $\begin{array}{c}31,7^{\circ} \\
\text { yıllık } \\
\text { optimum } \\
\end{array}$ & $\begin{array}{c}0^{\circ} \text { yıllık } \\
\text { optimum }\end{array}$ \\
\hline Ocak & 155 & 155 & 155 & 155 & 155 & 155 & 155 & 140 & 86 \\
\hline Şubat & 146 & 146 & 146 & 146 & 146 & 146 & 148 & 141 & 103 \\
\hline Mart & 197 & 197 & 206 & 206 & 206 & 206 & 206 & 204 & 169 \\
\hline Nisan & 226 & 226 & 226 & 229 & 229 & 229 & 229 & 227 & 214 \\
\hline Mayıs & 255 & 255 & 255 & 255 & 255 & 255 & 255 & 243 & 252 \\
\hline Haziran & 271 & 271 & 271 & 273 & 273 & 273 & 273 & 250 & 273 \\
\hline Temmuz & 282 & 282 & 282 & 283 & 283 & 283 & 283 & 263 & 282 \\
\hline Ağustos & 266 & 266 & 266 & 263 & 267 & 267 & 267 & 263 & 256 \\
\hline Eylül & 223 & 237 & 237 & 237 & 237 & 237 & 237 & 236 & 202 \\
\hline Ekim & 203 & 203 & 203 & 203 & 203 & 205 & 205 & 198 & 146 \\
\hline Kasım & 179 & 179 & 179 & 179 & 179 & 179 & 179 & 162 & 102 \\
\hline Aralık & 154 & 154 & 154 & 154 & 154 & 154 & 154 & 135 & 78 \\
\hline Toplam & 2557 & 2571 & 2580 & 2583 & 2587 & 2589 & 2591 & 2462 & 2163 \\
\hline $\begin{array}{c}\text { Üretimdeki } \\
\text { artış }\end{array}$ & 95 & 109 & 118 & 121 & 125 & 127 & 129 & 0 & -299 \\
\hline Verim $(\%)$ & 3,86 & 4,43 & 4,79 & 4,91 & 5,08 & 5,16 & 5,24 & 0 & $-12,14$ \\
\hline
\end{tabular}


$31,7^{\circ}$ yıllık optimum eğim açısı olup GES elektrik üretiminin $2462 \mathrm{kWh}$ ile maksimum değere ulaştı̆̆ durum ile karşılaştırılma yapılmıştır. Karşılaştırmada güneş paneli eğim açısının yılda farklı aylarda 8'li gruplandırmada üretim artışının $129 \mathrm{MWh}$ ve verimin \%5,24 oran ile en yüksek, 2'li gruplandırmada ise üretim artışının $95 \mathrm{MWh}$ ve \%3,86 oran ile en düşük artışın olduğu tespit edilmiştir. Bu değerlerin literatürdeki benzer çalışmalarla uyumlu olduğu görülmüştür $[8,9,10]$.

Panelin $31,7^{\circ}$ lik eğim açısının yatay $\left(0^{\circ}\right)$ konuma göre karşılaştırılmasında yatay konumdan $299 \mathrm{MWh}$ daha fazla elektrik üretimi gerçekleşerek verimin \%12,14 orana yükseldiği görülmüştür. Diğer taraftan, $31,7^{\circ}$ 'lik eğim açısının yılda $8^{\prime}$ li gruplandırma ile karşılaştırıldığında ise $8^{\prime}$ 'li gruplandırmanın $129 \mathrm{MWh}$ daha fazla elektrik üretimi ile verimin \%5,24 oranında arttığ 1 tespit edilmiştir.

Ayrıca Tablo 3'de görüldügü üzere, 2'li gruplandırma ile 3'lü gruplandırma arasındaki üretim artış farkı $14 \mathrm{MWh}$ ve \%0,57 oranı iken, 7'li gruplandırma ile 8'li gruplandırma arasındaki üretim artış farkı 2 MWh ve \%0,08 oranı ile gerçekleşmiştir. Bu fark gruplandırma sayısı arttıkça üretim miktarı artışının azaldığını göstermektedir.

Güneş paneli eğim açısının yılda farklı aylarda 8 defa değiş̧irilen gruptaki üretim artışının $2591 \mathrm{MWh}$ ve verimin $\% 5,24$ olduğu durum dikkate alındığında; $1500 \mathrm{~kW}$ kurulu güce sahip GES kurulması yerine $\% 5,24$ oranında, yaklaşık 1425 kW'lik kurulu güce sahip bir GES yeterli olacaktır.

Bu kapsamda, GES'in ilk yatırım maliyeti ve geri ödeme süresi yeniden incelenmiştir. Kurulması öngörülen GES'de ilk yatırım maliyetinin belirlenmesi için piyasa araştırması yapılmıştır. $1425 \mathrm{~kW}$ kurulu güce sahip GES'in kurulması için gerekli olan panel, inventer, ekipmanlar ve alınacak müşavirlik hizmeti için toplam 6.379.287 TL olarak hesaplanmış olup Tablo 4'de verilmiştir.

Tablo 4. GES'de panel ve ekipman listesi ve fiyatı

\begin{tabular}{lcccc}
\hline Malzeme adı & Adet & $\begin{array}{c}\text { Birim fiyat } \\
(\boldsymbol{T L})\end{array}$ & $\begin{array}{c}\text { Toplam } \\
\text { fiyat }(\boldsymbol{T L})\end{array}$ & $\begin{array}{c}\text { Maliyetteki } \\
\text { payı (\%) }\end{array}$ \\
\hline GES paneli (Mono $380 \mathrm{~W})$ & 3750 & 782 & 2.932 .500 & 54,2 \\
\hline İnverter (100 KW) & 13 & 68.600 & 891.800 & 16,5 \\
\hline Taşıyıcı sistem (Aliminyum) & 3750 & 95 & 356.250 & 6,6 \\
\hline Eğim açısı değişimi için basit düzenek & 3750 & 9,5 & 35.250 & 0,7 \\
\hline Kablo, pano vb. malzeme ve kurulum & 1 & 1.140 .000 & 1.140 .000 & 21,1 \\
\hline Müşavirlik hizmetleri & 1 & 50.000 & 50.000 & 0,9 \\
\hline Toplam (KDV hariç) & & & 5.406 .175 & \\
\hline Toplam gider (\%18 KDV dahil) & & & & \\
\hline
\end{tabular}

Tablo 4'de toplam maliyet içerisinde en büyük paylar \%54,2 GES panellerine, $\% 21,1$ ile kablo, pano vb. kuruluma ve \% 16,6 ile inventere aittir. Taşıyıcı ve ilave basit düzeneğin GES içerisindeki payı \%7,3 olup toplam maliyet içindeki oldukça düşük kalmaktadır.

GES tarafından yat limanı ihtiyacı olan enerjinin karşılanması durumunda Enerji Piyasası Düzenleme Kurumu'nun (EPDK) belirlemiş olduğu fiyat tarifesi [17] esas alınarak yapılan hesaplamada; üretilecek olan elektrikten yılda 2.045.432 TL tasarruf yapılabileceği hesaplanmıştır.

Yatırım projelerinde işletmeler yapacakları yatırım kararını, ilk yatırımın maliyetinin geri ödeme süresi belirlemektedir. Literatürde GES'lerin geri ödeme süreleri 4 yıla kadar düştüğü görülmektedir [18]. 
Yat limanına yapılacak GES yatırımının geri ödeme süresini belirlemede İndirgenmiş Geri Ödeme Süresi Yöntemi kullanılmış olup, Eşitlik (5)'e göre hesaplanmıştır [19].

$$
\sum_{t=0}^{m-1} \frac{I_{t}}{(1+i)^{t}}=\sum_{t=m}^{n} \frac{A_{t}}{(1+i)^{t}}
$$

Burada;

$m$; yatırımın kuruluş dönemi uzunluğunu

$I_{t} ; t$ yılda katlanılan yatırım maliyetini

$n$; yatırımın kuruluş dönemi ile ekonomik ömür süresi

$A_{t} ; t$ yılda ortaya çıkan net nakit akışını

$i$; iskonto oranın

ifade etmektedir.

Çalışmada yatırımın bir yıl gibi kısa bir sürede tamamlandığı, bugünkü değeri ile yılda 2.045.432 TL net getiri sağladığı ve \%12 iskonto oranı kabul edilmiştir. Bu kabuller çerçevesinde Tablo 5'te, İndirgenmiş Geri Ödeme Süresi Yöntemine göre GES ilk yatırım maliyet ve geri ödeme süresi verilmiştir.

Tablo 5. Indirgenmiş geri ödeme süresine göre GES yatırımı geri ödeme süresi

\begin{tabular}{|c|c|c|c|c|c|}
\hline & $\begin{array}{l}\text { Net akış } \\
\text { (TL) }\end{array}$ & $\begin{array}{l}\text { İndirgenmiş net } \\
\text { nakit akışları (TL) }\end{array}$ & $\begin{array}{l}\text { Birikimli indirgenmiş } \\
\text { net nakit akışı (TL) }\end{array}$ & $\begin{array}{l}\text { Kalan ödeme } \\
\text { (TL) }\end{array}$ & $\begin{array}{l}\text { Geri ödeme } \\
\text { süresi (yll) }\end{array}$ \\
\hline Temel yıl (0) & -6.379 .287 & -6.379 .287 & & & \\
\hline 1. y1l & 2.045 .432 & 1.826 .279 & 1.829 .053 & 4.553 .008 & \\
\hline 2. y1l & 2.045 .432 & 1.630 .606 & 3.456 .884 & 2.922 .403 & \\
\hline 3. y1l & 2.045 .432 & 1.455 .898 & 4.912 .783 & 1.466 .504 & \\
\hline 4. y1l & 2.045 .432 & 1.299 .909 & 6.212 .692 & 166.595 & \\
\hline 5. y1l & 2.045 .432 & 1.160 .633 & 7.373 .325 & -994.038 & 4,14 \\
\hline
\end{tabular}

Yapılan hesaplama sonucunda GES'in ilk yatırım maliyeti olan 6.379.287 TL'nin geri ödeme süresinin 4,14 yıl olduğu hesaplanmıştır. Çalışmada $n=5$ yılın sonrasında hesaplama yapılmamıştır.

Yıllık 31,7 optimum eğim açısı ile $1500 \mathrm{~kW}$ kurulu güce sahip olan GES'in kurulması için ilk yatırım maliyetinin 6.612.951 TL ve bu maliyetin geri ödeme süresinin ise 4,34 y1l olduğu daha önceki çalışmada bulunmuştur [20].

Bu kapsamda, 8'li gruplandırmada yat limanı için kurulu gücün 1500 kW'den 1425 kW'a düşmesinde durumunda GES' in ilk yatırım maliyeti 233.664 TL daha az olacaktır. Illk yatırım maliyetinin geri ödeme süresi ise 4,34 yıldan 4,14 y1la düşecektir.

Çalışmanın daha önce yapılan çalışmalarla uyumlu olduğu görülmüştür [18, 20].

\section{IV.SONUC}

Yapılan hesaplamalar sonucunda; Fethiye İlçesindeki bir yat limanının elektrik ihtiyacının GES ile karşılanması durumunda güneş paneli eğim açısının basit aparatlarla yılda birkaç defa değiştirilmesi durumunda güneş ışınımından daha fazla faydalanılacaktır. Bu fayda GES'den elde edilecek olan elektrik enerjisi verimini artıracağı anlamı taşımaktadır. 
Güneş panelinin hem $8^{\circ}$ ve hem de $59^{\circ}$ eğim açılarında ardışı üç ay maksimum enerji elde edilmesi panel açı değişim sayısını azaltmıştır.

8'li gruplandırmanın üzerinde gruplandırma oluşturulmasının GES verimine katkısı olmadığı anlaşılmıştır.

Aylardaki gruplandırma sayısı arttıkça veriminde arttı̆̆ı, ancak gruplar arası artış oranında bir azalma olduğu görülmüştür.

Yat limanına kurulacak $1500 \mathrm{~kW}$ kurulu güce sahip GES'de sadece eğim açısının y1lda farklı aylarda 8 defa değiştirilen gruptaki üretimin 129 MWh en yüksek, y1lda 2 defa değişim olan gruptaki üretimin 95 MWh ile en düşük artışın olduğu tespit edilmiştir.

Panelin yılda 2 defa ile 8 defa değişimi arasında \%1,38 gibi önemli bir verim artışı olduğu saptanmıştır.

Yılda 8 defa değiştirilen grup dikkate alındığında; yat limanına kurulacak GES için 1500 kW yerine $1425 \mathrm{~kW}$ 'lik bir güç yeterli olacaktır.

Yat limanlarına yapılacak olan GES yatırımlarında panel açısının yılda 8 defa değiştirilmesi ile aynı enerji elde edilmekle birlikte ilk yatırım maliyetinde 233.664 TL azalma oluşmuştur.

Yılda 8 defa değiştirilen gruptaki üretim artışının, 1500 kW güce göre GES ilk yatırım maliyetinin geri ödeme süresinde 0,2 yıl gibi bir azalma olduğu tespit edilmiştir.

Yat limanlarına GES'lerin kurulması ile enerji tasarrufu politikaları ile uyumlu, ülkemiz ekonomisine ve çevreyi korumaya olumlu katkı sağlayacaktır.

Bu çalışmanın literatürle uyumlu olduğu görülmüş olup, ülkemizdeki yat limanlarında GES kurulmasına yönelik çalışmalara katkı sunacaktır.

\section{KAYNAKLAR}

[1] S. Roberts, and N. Guariento, Building Integrated Photovoltaics A Handbook, Berlin, Germany: Birkhauser Press, 2009.

[2] K. Ülgen, "Optimum Tilt Angle for Solar Collectors. Energy Sources, Part A: Recovery," Utilization, and Environmental Effects, c. 28 s. 13, ss. 1171-1180, 2006, doi:10.1080/00908310600584524

[3] A. Çağlar, "Farklı derece-gün bölgelerindeki şehirler için optimum eğim açısının belirlenmesi," Süleyman Demirel Üniversitesi Fen Bilimleri Enstitüsü Dergisi, c. 22, s. 2, ss. 849-854, 2018, doi:10.19113/sdufbed.94899

[4] R. Tallab and A. Malek, "Predict system efficiency of 1 MWc photovoltaic power plant interconnected to the distribution network using PVsyst software," presented at 3rd International Renewable and Sustainable Energy Conference (IRSEC), Marrakech, Morocco, 2015.

[5] W. G. Le Roux, "Optimum tilt and azimuth angles for fixed solar collectors in South Africa using measured data," Renewable Energy, vol. 96, pp. 603-612, 2016.

[6] E. Y1ldırım and M.A. Aktacir, "Investigation of azimuth and tilt angle effects on building integrated photovoltaic systems," Journal of the Faculty of Engineering and Architecture of Gazi University, vol. 34 no. 2, pp. 609-619, 2019.

[7] M. Aydın ve B. Yeşilata, "Fotovoltaik panellerde eğim açısı etkisinin deneysel olarak saptanmas1," Termodinamik Dergisi, c. 148, ss. 88-98, 2004. 
[8] T. Khatib, A. Mohamed, M. Mahmoud and K. Sopian, "Optimization of the Tilt Angle of Solar Panels for Malaysia," Energy Sources, Part A: Recovery, Utilization, and Environmental Effects, vol. 37, no. 6, pp. 606-613, 2015.

[9] M. Bilgili ve M. Dağtekin, "Fotovoltaik piller ile elektrik üretiminde uygun eğim açısının ve yıllık oluşan enerji farkının belirlenmesi," Gaziosmanpaşa Bilimsel Araştırma Dergisi, c. 6, ss. 156$167,2017$.

[10] W.D. Lubitz, "Effect of manual tilt adjustments on incident irradiance on fixed and tracking solar panels," Applied Energy, v. 88, no. 5, pp. 1710-1719, 2011, doi:10.1016/j.apenergy.2010.11.008

[11] Enerji ve Tabi Kaynaklar Bakanlığı. (2020, 15 Aralık). Güneş enerji potansiyeli atlası (GEPA) [Çevrimiçi]. Erişim: http://www.yegm.gov.tr/MyCalculator/.

[12] Tersaneler ve Kıyı Yapıları Genel Müdürlügü, (2021, 10 Ocak). Yat limanı bilgileri [Çevrimiçi]. Erişim: https://tkygm.uab.gov.tr/uploads/pages/limanlar-ve-kiyi-yapilari/3-yat-limanlari-bilgileri.pdf.

[13] A.R. Dal ve F. Yılmaz, "Ticari bir yat limanının elektrik ihtiyacının fotovoltaik (PV) teknoloji ile karşılanmasına yönelik bir inceleme," Uludağ Üniversitesi Mühendislik Fakültesi Dergisi, c. 25 s. 3 , ss. 1189-1204, 2020.

[14] European Commission. (2020, December 15). Photovoltaic geographical information system (PVGIS) [Online]. Available: https://ec.europa.eu/jrc/en/PVGIS/docs/methods.

[15] T. Huld, G. Friesen, A. Skoczek, R.P. Kenny, T. Sample, M. Field and E.D. Dunlop, "A powerrating model for crystalline silicon PV modules," Solar Energy Materials \& Solar Cells, v. 95, pp. 33593369, 2011.

[16] D. Vasarevicius and R. Martavicius, "Solar irradiance model for solar electric panels and solar thermal collectors in Lithuania," Electronics and Electrical Engineering, vol. 108, no. 2, pp. 3-6, 2011.

[17] Enerji Piyasası Düzenleme Kurumu, (2020, 15 Aralık). Elektrik Faturalarına Esas Tarife Tablolar1. https://www.epdk.org.tr/Detay/Icerik/3-1327/elektrik-faturalarina-esas-tarife-tablolari.

[18] E. Sulukan, "İstanbul'da bir fotovoltaik sistemin tekno-ekonomik ve çevresel analizi," Pamukkale Üniversitesi Mühendislik Bilimleri Dergisi, c. 26, s. 1, ss. 127-132, 2020.

[19] H. Eski ve Ö. Armaneri, Mühendislik Ekonomisi, Ankara: Gazi Kitapevi, 2006.

[20] A.R. Dal ve F. Yılmaz, "Yat limanı için güneş enerjisi sistemi yatırımının maliyet ve çevresel analizi," 4. Uluslararası Ekonomi, Finans ve Enerji Kongresi, Niğde- Türkiye, 2020, ss. 645-655. 